\section{ornl}

OAK RIDGE

NATIONAL

LABORATORY

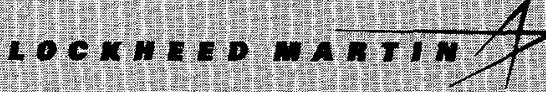

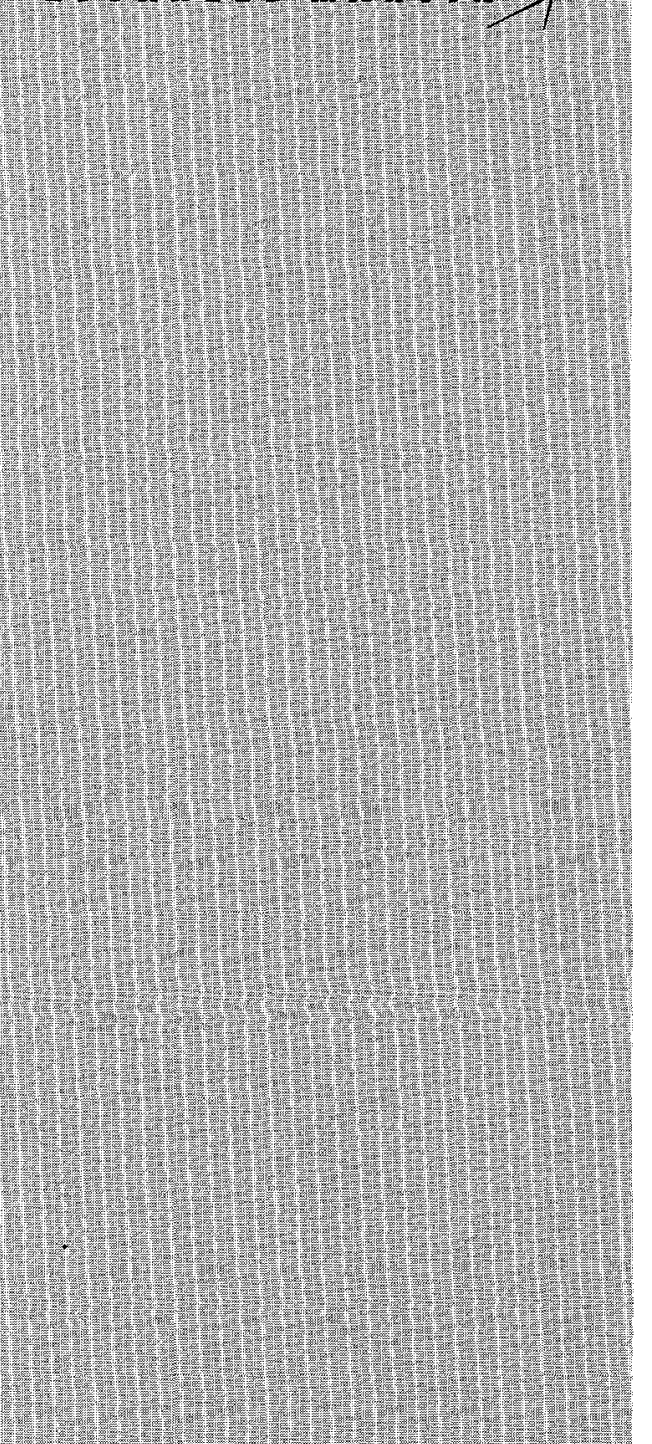

MAMAGED AND OPERATED BY

LOCKHEED WARTI ENERGY RESEARGI CORPORATON FOA THEVUTED STATES

DEPARTMEIT OF ENERGY

\section{CONFIRMATORY RADIOLOGICAL SURVEY FOR THE 190-C MAIN PUMPHOUSE FACILITY DECOMMISSIONING AT THE HANFORD SITE, RICHLAND, WASHINGTON}

\author{
R. L. Coleman \\ G. H. Forbes \\ RECEIVED \\ JUL 101997 \\ OSTI
}


This report has been reproduced directly from the best available copy.

Available to DOE and DOE contractors from the Office of Scientific and Technical Information, P. O. Box 62, Oak Ridge. TN 37831: prices available from (423) 576-8401, FTS 626-8401.

Available to the public from the National Technical Information Service, U.S. Department of Commerce, 5285 Port Royal Road, Springfield, VA 22161.

This report was prepared as an account of work sponsored by an agency of the United States Government. Neither the United States Government nor any agency thereof, nor any of their employees, makes any warranty, express or implied, or assumes any legal liability or responsibility for the accuracy, completeness, or usefulness of any information, apparatus, product, or process disclosed, or represents that its use would not infringe privately owned rights. Reference herein to any specific commercial product, process, or service by trade name. trademark, manufacturer, or otherwise, does not necessarily constitute or imply its endorsement, recommendation, or favoring by the United States Government or any agency thereof. The views and opinions of authors expressed herein do not necessarily state or reflect those of the United States Government of any agency thereof. 


\section{DISCLAIMER}

Portions of this document may be illegible electronic image products. Images are produced from the best available original document. 


\title{
Confirmatory Radiological Survey for the 190-C Main Pumphouse Facility Decommissioning at the Hanford Site, Richland, Washington
}

\author{
R. L. Coleman \\ G. H. Forbes \\ Project Staff \\ M. K. Jensen \\ S. M. Smith \\ V.P. Patania \\ Report Issued - June 1997 \\ Prepared for the \\ Decontamination and Decommissioning Branch \\ Division of Northwestern Area Programs \\ Office of Environmental Restoration \\ Prepared by the \\ Oak Ridge National Laboratory \\ Environmental Technology Section \\ Grand Junction, Colorado 81502 \\ managed by \\ LOCKHEED MARTIN ENERGY RESEARCH CORPORATION \\ Oak Ridge, Tennessee 37831-7606 \\ for the \\ U.S. DEPARTMENT OF ENERGY \\ under contract DE-AC05-960R22464
}

*ORNL; Oak Ridge, TN 



\section{TABLE OF CONTENTS}

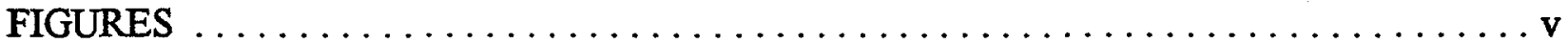

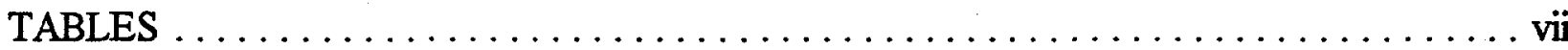

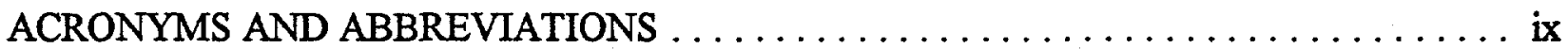

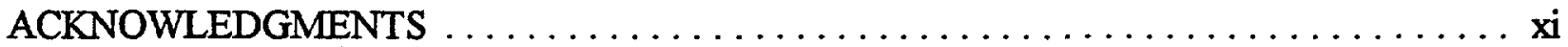

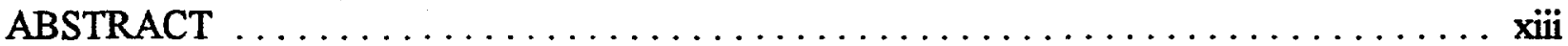

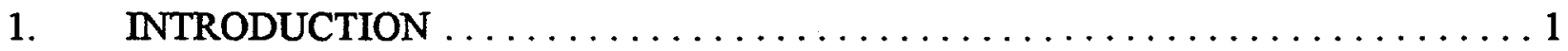

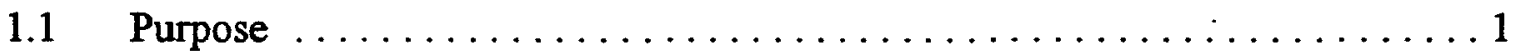

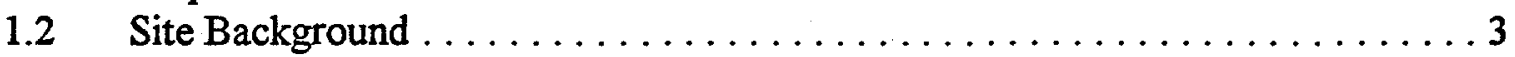

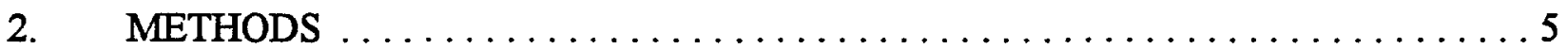

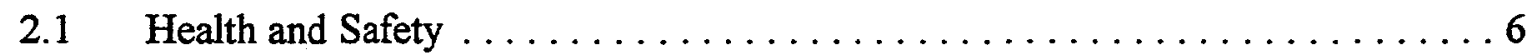

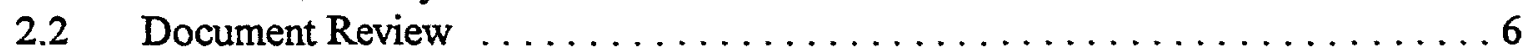

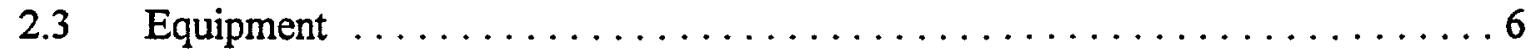

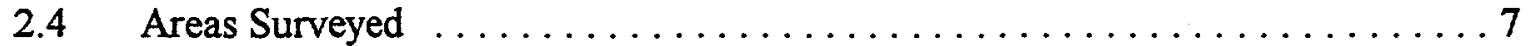

2.4.1 Basement Trenches . . . . . . . . . . . . . . . . . . . 7

2.4 .2 Tunnels . . . . . . . . . . . . . . . .

2.4.3 Main Floor Bay Area $\ldots \ldots \ldots \ldots \ldots \ldots \ldots \ldots \ldots$

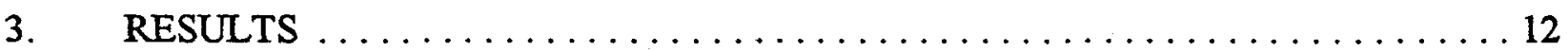

3.1 Background Measurements . . . . . . . . . . . . . . . . . 12

3.2 Radionuclides and Detection Efficiencies $\ldots \ldots \ldots \ldots \ldots \ldots \ldots \ldots \ldots$

3.3 Trench Data . . . . . . . . . . . . . . . . . . . . . . . . . . . . 13

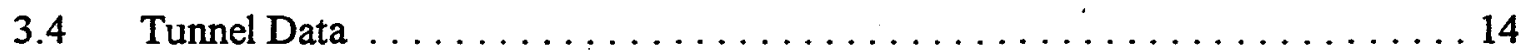

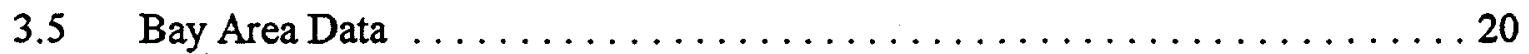

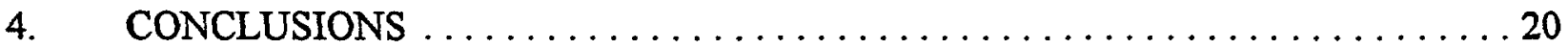

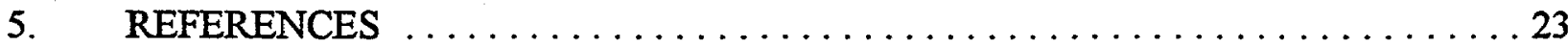

APPENDIX A Verification Statement for 190-C Main Pumphouse Facility at the Hanford Site, Richland, Washington 



\section{FIGURES}

1 Location of $190-C$ Main Pumphouse Facility at Hanford Site . . . . . . . . . . . 2

$2 \quad 190-\mathrm{C}$ basement trenches showing trench layout and reference grid $\ldots \ldots \ldots . \ldots$

$3 \quad 105-\mathrm{C}$ water process tunnels showing fixed-point measurement locations $\ldots \ldots \ldots 10$

$4 \quad 190-\mathrm{C}$ building high bay area with grid layout positions and area of scan $\ldots \ldots \ldots 11$

5 190-C basement trench detail showing region of interest near the north

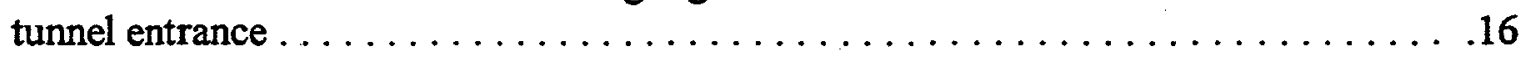





\section{TABLES}

1 Surface contamination guidelines, DOE Order $5400.5 \ldots \ldots \ldots \ldots \ldots$

2 Detector background measurements $\ldots \ldots \ldots \ldots \ldots \ldots \ldots \ldots \ldots \ldots$

3 Surface contamination measurements from the $190-\mathrm{C}$ basement trenches $\ldots \ldots \ldots 15$

4 Surface contamination measurements from the $105-\mathrm{C}$ water process tunnels $\ldots \ldots \ldots 17$

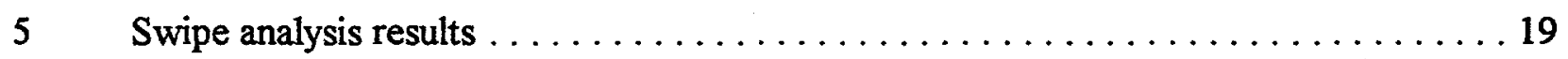

6 Surface contamination measurements from the $190-\mathrm{C}$ main floor bay area $\ldots \ldots \ldots 21$ 


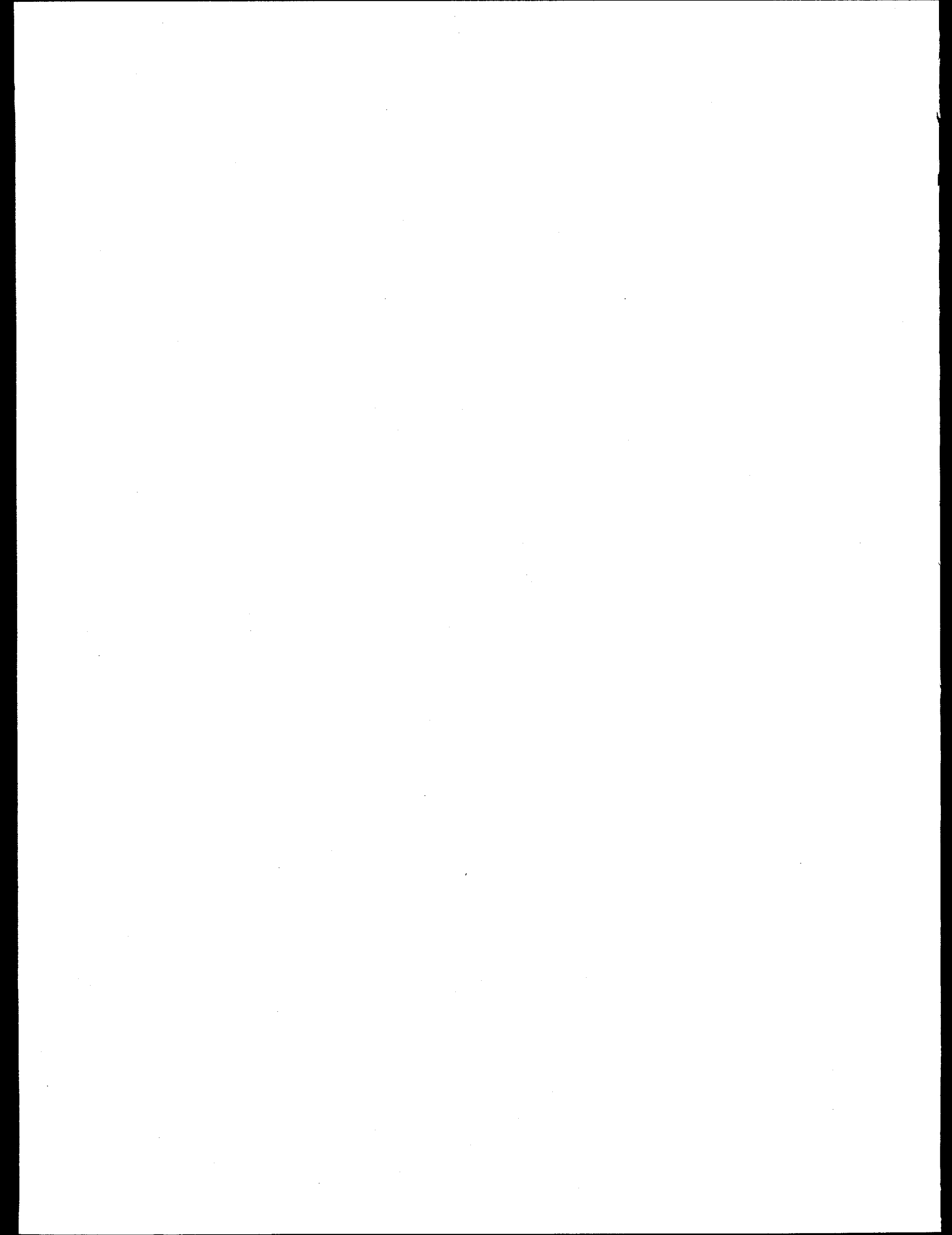




\section{ACRONYMS AND ABBREVIATIONS}

BHI

Bechtel Hanford, Inc.

cpm counts per minute

D\&D

Decontamination and Decommissioning

DOE

Department of Energy

DOE/RL

Department of Energy/Richland

dpm

DQO

disintegrations per minute

EM

data quality objective

ETS

GM

Environmental Restoration and Waste Management

IVC

Environmental Technology Section

MDA

Geiger-Mueller

independent verification contractor

$\mathrm{NaI}$

minimum detectable activity

ORNL/GJ

sodium iodide

QA

RAC

Oak Ridge National Laboratory/Grand Junction, Colorado

quality assurance

remedial action contractor

$\mathrm{ZnS}(\mathrm{Ag}) \quad$ zinc sulfide (silver) 



\section{ACKNOWLEDGMENTS}

This project was sponsored by the U. S. Department of Energy under contract DE-AC05960R22464 with Lockheed Martin Energy Research Corporation. The authors wish to acknowledge the following Oak Ridge National Laboratory/Grand Junction, Colorado staff: D. K. Halford for providing valuable technical support; P. D. Roundtree for word processing of the report; E. K. Roemer for preparation of graphics; and C. A. Little, for Environmental Technology Section management. The authors would also like to thank K. J. Brown in the Oak Ridge, Tennessee, office for technical editing. 



\begin{abstract}
An independent assessment of remedial action activities at the 190-C Main Pumphouse Facility at the Hanford Site, Richland, Washington has been accomplished by the Oak Ridge National Laboratory Environmental Assessments Group. The purpose of the assessment was to confirm the site's compliance with DOE applicable guidelines and provide independent measurements of the activity levels in the $190-\mathrm{C}$ trenches and $105-\mathrm{C}$ process water tunnels. The assessment included reviews of the Decontamination and Decommissioning Plan and data provided in the preand post-remedial action surveys. An on-site independent verification survey of the facility was conducted during the period of November 19-21, 1996.

The independent verification survey included beta and gamma scans, smears for removable contamination, and direct measurements for beta-gamma activity in the trenches and tunnels. The same measurements and scans, with the addition of alpha measurements, were performed on the floor in the filter repair confinement area. The facility was also spot-checked for direct alpha and beta-gamma activity.

Based on findings from this survey, together with data provided by the remedial action contractor, the building surfaces in the 190-C Main Pumphouse Facility, with the exception of the trenches and tunnels, conform to the applicable guidelines for surface contamination at this site (Source: Radiation Protection of the Public and the Environment, DOE Order 5400.5, U. S. Department of Energy, 1990). Although the contamination levels in the tunnels and trenches exceeded the established DOE release limits, the average radiation levels in these areas were found to be less than those reported by the remedial action contractor.
\end{abstract}




\section{Confirmatory Radiological Survey for the 190-C Main Pumphouse Facility Decommissioning at the Hanford Site, Richland, Washington}

\section{INTRODUCTION}

The Department of Energy Richland Operations Office has assigned Bechtel Hanford, Inc. (BHI) the responsibility of implementing the Decontamination and Decommissioning (D\&D) Program at the Hanford Site at Hanford, Washington. Included for decontamination and demolition is the 190-C Main Pumphouse Facility located in the 100-B and C areas of the site (Fig. 1).

The decommissioning objective for this facility is to remove all radioactively contaminated material (except that in the trenches and tunnels) such that the remaining amounts are consistent with the limits for release published in DOE Order 5400.5 (U.S. DOE 1990). The U. S. DOE Richland Operations Office has the authority to approve supplemental limits specific to D\&D projects at the Hanford Site. Supplemental limits on concentrations of residual radioactive material are derived using the ALARA process when circumstances exist in which otherwise applicable authorized limits are inappropriate or impracticable to apply. The radiological conditions of the trenches and tunnels have been previously evaluated and, based on the evaluations, a request will be made for approval of supplemental authorized limits of residual radioactive contamination levels associated with this facility. At a later date, the facility will be demolished to a level about $1 \mathrm{~m}(3 \mathrm{ft})$ below grade. The basement structure, located deeper than

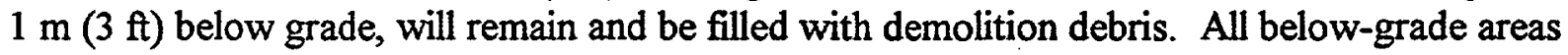
will be filled to eliminate future subsidence (Kennedy and Moeller 1996).

\subsection{Purpose}

It is the policy of DOE to perform independent (third party) verifications of the effectiveness of remedial actions conducted within the various remedial action programs (U.S. DOE 1988). The Oak Ridge National Laboratory/Grand Junction, Colorado (ORNL/GJ) Environmental Technology Section (ETS) has been assigned by the D\&D Branch Division of the Northwestern Area Programs Office of Environmental Restoration and Waste Management (EM) as the independent verification contractor (IVC) for this decommissioning project at Hanford. The scope includes independent verification of the filter repair confinement area and independent measurements of the activity levels in the 105-C water tunnels and 190-C trenches.

The radiological contaminants of interest for the 190-C trenches and the 105-C tunnels are ${ }^{90} \mathrm{Sr}>$ ${ }^{137} \mathrm{Cs}>{ }^{60} \mathrm{Co}>{ }^{152} \mathrm{Eu}>{ }^{239} \mathrm{Pu}>{ }^{241} \mathrm{Am}$. The activity percentage of strontium is $53 \%$ and of cesium is $46 \%$ (Kennedy and Moeller 1996). Based on information obtained from technical smears, the radionuclides identified in the 190-C Main Pumphouse Facility in sequence of the most abundant are ${ }^{154} \mathrm{Eu}>{ }^{155} \mathrm{Eu}>{ }^{60} \mathrm{Co}>{ }^{90} \mathrm{Sr}$. There is approximately 1.5 times more ${ }^{60} \mathrm{Co}$ than ${ }^{90} \mathrm{Sr}$ and 


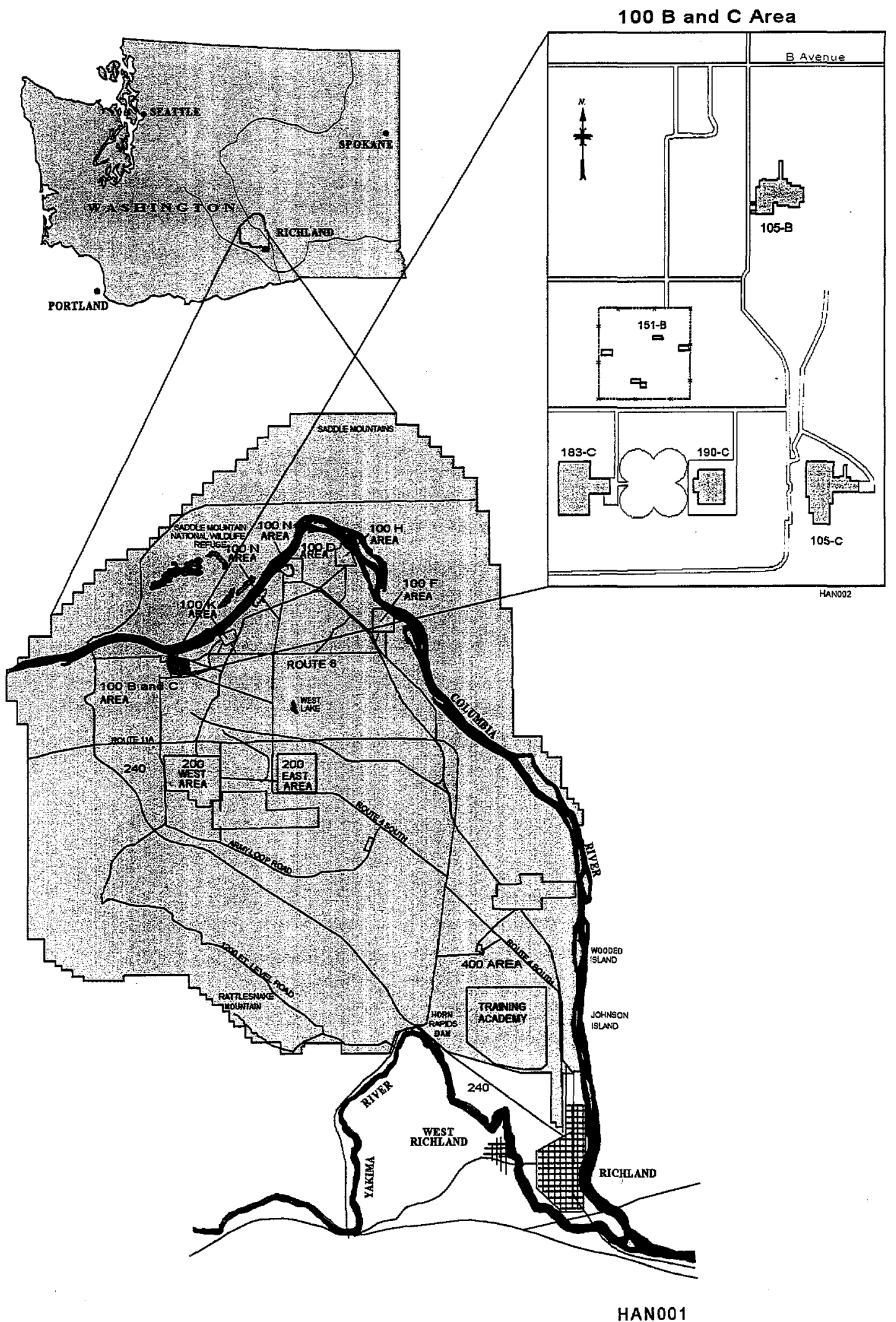

Fig. 1. Location of 190-C Main Pumphouse Facility at Hanford Site. 
approximately 23 times more cobalt and europium combined than strontium (Harris and Winslow 1996). The surface contamination guidelines for the radionuclides of interest are shown in Table 1 (U.S. DOE 1990). Note that the release limit for ${ }^{90} \mathrm{Sr}$ for this case is $5000 \mathrm{dpm} / 100 \mathrm{~cm}^{2}$ averaged over $1 \mathrm{~m}^{2}$ because the strontium has never been chemically separated. This is the release limit for all radionuclides of real concern in the 190-C building.

\subsection{Site Background}

The 190-C Main Pumphouse Facility was used in support of the reactor cooling water treatment process for the 105-C Reactor. The facility is constructed of reinforced concrete, structural steel framework, transite siding, and a transite roof. The building is $60 \mathrm{~m}(196 \mathrm{ft})$ long by $49 \mathrm{~m}(160$ $\mathrm{ft}$ ) wide and contains a full-sized basement. Located on the main floor are ten pumping stations with a 10,000-gpm capacity each. The building accommodates the pump room, solids mix room, electrical cubicle room, offices, control room, instrument shop, air compressor station, valve pits and the entrances to the water tunnels in support of pumping the reactor cooling process water for the 105-C Reactor. The basement contains the cooling water/piping system, compressed air and steam piping, fluid coupling heat exchanger, and the solids injection system. Located at the northeast and southeast corners of the basement are the entrances to the 105-C water tunnels leading to the reactor. Each of these tunnels is approximately $3.3 \mathrm{~m}(10 \mathrm{ft})$ wide by $4 \mathrm{~m}(12 \mathrm{ft})$ high by $152 \mathrm{~m}(500 \mathrm{ft})$ and contain process water and steam piping (Marske 1996).

Water from the Columbia River passed through filter beds located in 183-C and was then pumped through 190-C on its way to the reactor coolant system. The water did not return through 190-C and 183-C. Characterization Report on the 190-C Main Pumphouse Facility, BHI-00523, confirms that the interior of piping and equipment is not radiologically contaminated.

Both the 190-C Pumphouse and the 105-C process water tunnels were considered to be radiologically uncontaminated facilities for most of their operation because they were on the intake (not discharge) side of the water coolant system. However, during the operation of the $\mathrm{C}$ Reactor, reactor coolant water occasionally entered the tunnels from the 105-C facility and deposited radioactive contamination on the floors of the tunnels and trenches of the 190-C basement. These trenches were about $0.7 \mathrm{~m}(2.5 \mathrm{ft})$ wide by $0.6 \mathrm{~m}(2 \mathrm{ft})$ deep, and were used to channel water away from the pump station foundations and other floor areas (Kennedy and Moeller 1996). There is no indication that the coolant ever escaped the collection trench and sump collection areas of the basement.

The facility was also used as a storage location for 105-N Reactor miscellaneous material. A confinement for repair of filters from the 117-N filter building was constructed in the north end of the main bay area on the main floor of building 190-C in 1970. This repair facility was in use until 1987 in support of 105-N activities. During filter changing operations, containment was lost and contamination was spread in the air of the 190-C facility (Harris and Winslow 1996). 
Table 1. Surface contamination guidelines

\begin{tabular}{|c|c|c|c|}
\hline \multirow{2}{*}{ Radionuclides $^{b}$} & \multicolumn{3}{|c|}{$\begin{array}{l}\text { Allowable total residual surface contamination } \\
\qquad\left(\mathrm{dpm} / 100 \mathrm{~cm}^{2}\right)^{a}\end{array}$} \\
\hline & Averaged $^{c}$ & Maximum $^{d e}$ & Removable ${ }^{d, f}$ \\
\hline $\begin{array}{l}\text { Transuranics, I-125, I-129, } \\
\text { Ra-226, Ac-227, Ra-228, } \\
\text { Th-228, Th-230, Pa-231 }\end{array}$ & $\begin{array}{l}\text { RESERVED } \\
(100)\end{array}$ & $\begin{array}{l}\text { RESERVED } \\
(300)\end{array}$ & $\begin{array}{l}\text { RESERVED } \\
\text { (20) }\end{array}$ \\
\hline $\begin{array}{l}\text { Th-natural, Sr-90, I-126, } \\
\text { I-131, I-133, Ra-223, } \\
\text { Ra-224, U-232, Th-232 }\end{array}$ & 1,000 & 3,000 & 200 \\
\hline $\begin{array}{l}\text { U-natural, U-235, U-238, } \\
\text { and associated decay } \\
\text { products, alpha emitters }\end{array}$ & 5,000 & 15,000 & 1,000 \\
\hline $\begin{array}{l}\text { Beta-gamma emitters } \\
\text { (radionuclides with decay } \\
\text { modes other than alpha } \\
\text { emission or spontaneous } \\
\text { fission) except } \mathrm{Sr}-90 \text { and } \\
\text { others noted above }\end{array}$ & 5,000 & 15,000 & 1,000 \\
\hline
\end{tabular}

${ }^{a}$ As used in this table, dpm (disintegrations per minute) means the rate of emission by radioactive material as determined by correcting the counts per minute measured by an appropriate detector for background, efficiency, and geometric factors associated with the instrumentation.

${ }^{b}$ Where surface contamination by both alpha- and beta-gamma-emitting radionuclides exists, the limits established for alpha- and beta-gamma-emitting radionuclides should apply independently.

'Measurements of average contamination should not be averaged over an area of more than $1 \mathrm{~m}^{2}$. For objects of less surface area, the average should be derived for each such object.

${ }^{d}$ The average and maximum dose rates associated with surface contamination resulting from betagamma emitters should not exceed $0.2 \mathrm{mrad} / \mathrm{h}$ and $1.0 \mathrm{mrad} / \mathrm{h}$, respectively, at $1 \mathrm{~cm}$.

${ }^{e}$ The maximum contamination level applies to an area of not more than $100 \mathrm{~cm}^{2}$.

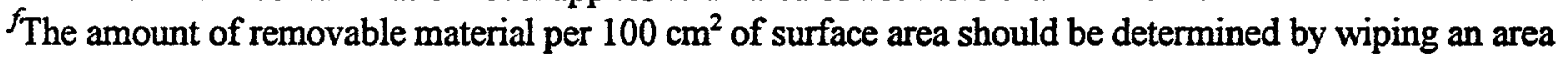
of that size with dry filter or soft absorbent paper, applying moderate pressure, and measuring the amount of radioactive material on the wiping with an appropriate instrument of known efficiency. When removable contamination on objects of surface area less than $100 \mathrm{~cm}^{2}$ is determined, the activity per unit area should be based on the actual area and the entire surface should be wiped. It is not necessary to use wiping techniques to measure removable contamination levels if direct scan surveys indicate that the total residual surface contamination levels are within the limits for removable contamination.

${ }^{8}$ This category of radionuclides includes mixed fission products, including the Sr-90 which is present in them. It does not apply to $\mathrm{Sr}-90$ which has been separated from the other fission products or mixtures where the Sr-90 has been enriched.

Source: Radiation Protection of the Public and the Environment, DOE Order 5400.5, U. S. Department of Energy, 1990. 
To evaluate if contamination from the filters could have significantly modified the source term for the 190-C trenches, additional smear samples have been taken from the HEPA filter area and analyzed by IT Hanford Co. The results of these analyses indicated that the radionuclide distribution for the HEPA filter contamination was a different mixture of radionuclides, not consistent with the radionuclide mixture found for the 190-C trenches or the 105-C tunnel. The HEPA filter contamination was mostly ${ }^{60} \mathrm{Co},{ }^{154} \mathrm{Eu}$ and ${ }^{152} \mathrm{Eu}$, with some ${ }^{90} \mathrm{Sr}$, while the contamination on the samples from the $190-\mathrm{C}$ trenches contained a significant amount of ${ }^{90} \mathrm{Sr}$ (Kennedy and Moeller 1996).

Most of the work scope for 190-C Main Pumphouse Facility, which is to radiologically decontaminate the facility and properly dispose of all radiological materials, has been performed. The scope was to remove the hazardous oils and greases from the pumps and valves along with the asbestos containing material steam piping/lagging/transite and associated components of the pump stations. The various hazardous materials (such as mercury switches, light bulbs, light ballasts, and polychlorinated biphenyl-contaminated oils) was also to be removed and properly disposed before completely dismantling the facility in a safe, efficient manner within state and federal regulations. Prior to demolition the site will be verified as free of radiological and hazardous contamination (Marske 1996). The exception is that the remaining radiological contamination in the 190-C trenches and the 105-C water tunnels will not be removed. Evaluations performed by others (Kennedy and Moeller 1996) have determined that authorized limits for the trenches and tunnels will represent a safe and cost-effective approach to their final disposition. A significant part of this survey was to provide independent measurements of the activity levels in these areas, which can be used to assess the accuracy of the data used when performing the dose modeling associated with these evaluations.

\section{METHODS}

A team from ORNL visited the 190-C Pumphouse Facility site and performed a scoping inspection in September 1996. An independent verification survey plan was developed based on both this inspection and the remediation survey data. ORNL conducted an independent confirmatory survey of the 190-C Main Pumphouse Facility and 105-C Water Process Tunnels on November 19-21, 1996. The survey team performed visual inspections, determined detector background responses for the building material, established survey grids, performed beta and gamma radiation scans, took smears for detection of removable activity, and collected direct beta, gamma and alpha radiation measurements. Data were evaluated and compared to guidelines set forth in DOE Order 5400.5 (U.S. DOE 1990). Information in addition to what is found here concerning survey protocols can be found in these procedural documents: Environmental Technology Section Procedures Mamual (ORNL 1993) and Measurement Applications and Development Group Guidelines (ORNL 1995). 


\subsection{Health and Safety}

IVC work activities followed $\mathrm{BHI}$ health and safety procedures that comply with requirements for protection from hazards identified in the Activity Hazard Analysis for 190-C, 100-C Area (BHI 1996), applicable radiation work permits for D\&D of Hanford facilities and the ORNL health and safety procedures and guidelines (Fasso 1996). The RAC provided a secure staging area for the IVC. When the IVC entered the contamination control zone, protective clothing was provided and disposed of by the RAC. The RAC also monitored access control and work site activities in the contamination control zone.

\subsection{Document Review}

Radiological characterization reports, engineering drawings, and post-remedial action survey documents were reviewed. Data were evaluated to assure that areas exceeding guidelines were identified and underwent remedial action. These reports were also reviewed for general thoroughness and accuracy.

\subsection{Equipment}

All equipment listed here had been calibrated in accordance with guidelines published in the report ORNL-6782 (ORNL 1995) prior to performing any measurements.

Direct Measurement Equipment: Direct surface contamination measurements for beta-emitting radionuclides were performed using Geiger-Mueller pancake type detectors. Two separate configurations were used: 1) Eberline HP-260 single detector models connected to Bicron Analyst $^{\mathrm{TM}}$ and Surveyor-M ${ }^{\mathrm{TM}}$ scaler/ratemeters; and 2) Ludlum model 44-89 quad-detector models connected to Bicron Analyst ${ }^{\mathrm{TM}}$ and Surveyor-M ${ }^{\mathrm{TM}}$ scaler/ratemeters. The single detector probes are similar to common pancake detectors used at all DOE facilities, while the quaddetector form is essentially just four of these same detectors encased within a single probe housing and electronically coupled to one output. It is important to note that all of these detectors are calibrated such that each detector responds to within $10 \%$ of one another. Using this acceptance protocol during calibration allows for the use of the same conversion factor for all detectors and requires that only one each of the detectors be used when collecting background measurements.

Direct gamma scans were performed using Victoreen 489-55 NaI(Tl) detectors connected to Victoreen Thyac-III ratemeters. These instruments are not used to measure exposure rate directly, but instead are simply used to locate anomalous areas of elevated gamma fluence from surfaces of interest. Similar to the portable beta instrumentation, each NaI detector used during this survey had been calibrated to respond within $10 \%$ of one another.

Direct surface contamination measurements for alpha-emitting radionuclides were performed using ORNL model Q-2101 $\mathrm{ZnS}(\mathrm{Ag})$ type probes connected to Bicron Analyst scaler ratemeters. 
Sample Analysis Equipment: Swipe (or smear) analyses for gross transferrable contamination were performed using a combination of a stationary Geiger-Mueller beta counter and a $\mathrm{ZnS}(\mathrm{Ag})$ alpha counter. In addition, gamma spectrometry measurements of collected media were performed using a stationary shielded hyper-pure germanium spectrometer.

\subsection{Areas Surveyed}

All direct surface contamination measurements collected during the course of this project were taken at contact with the material being measured. All beta scans were conducted such that the face of the probe remained within approximately $1 / 4$ to $1 / 2$ inch of the surface and all gamma scans were performed with the detector held to within 6 inches of the surface being evaluated. The following sections detail the measurement locations and the specific approach used for collecting survey data in that area.

It should be noted that there is no history of alpha-emitting radionuclides at this facility. Although low levels of alpha emitters had been previously detected during characterization and remediation exercises, the quantity present was always found to be much less than the beta-gamma-emitting radionuclides and are therefore not considered to be of concern. The alpha measurements collected during this survey were performed for completeness of confirming the lack of significant alpha emitters. As a point, if any significant alpha emissions were found on the aged concrete of this facility the first path of evaluation should be to determine whether the emissions were due to radon daughters which had plated out onto the surface.

\subsubsection{Basement Trenches}

Figure 2 shows a drawing of the 190-C basement area and displays the reference grid used for each of the trench segments. A grid referencing the lineal distance along the trench from a zero starting point was used for each trench. The perimeter trench encircles the entire basement area and is immediately adjacent to the outside basement wall. There are two trenches which cut across the entire span of the basement in a west-to-east direction with one additional trench that spans only the western half of the basement. These trenches were labeled trenches A, B and C, respectively, for the purpose of reference during this survey. All of this is shown graphically in Fig. 2 with the reference grid used for collecting data superimposed.

The entire trench area, which included the bottoms and sides of the trenches, had been painted prior to this survey. Based on conversations with site personnel associated with painting activities, it was determined that approximately three coats of paint had been used to prevent the transfer of any existing contamination by workers. In addition, many sections of the trench lengths were obstructed from easy access by piping.

The entire length of each trench was scanned with pancake type detectors for the purpose of locating localized areas of elevated beta-emitting radionuclides, with the exception of Trench $\mathbf{C}$. Randomly selected sections of the trench were also scanned with $\mathrm{NaI}$ detection equipment with 


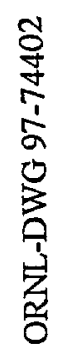
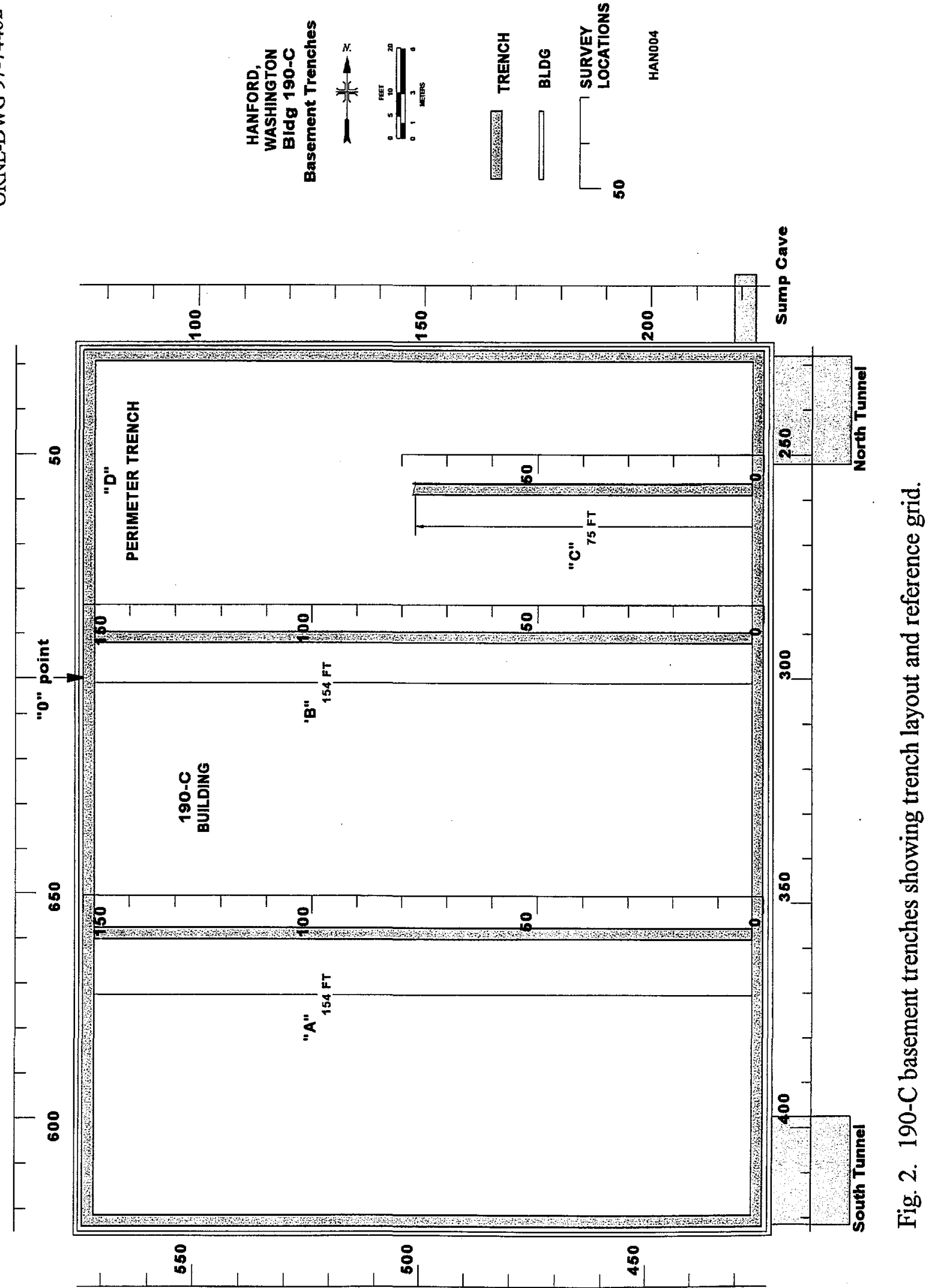
the purpose of locating significant amounts of gamma-emitting radionuclides which may have soaked into cracks or expansion joints. In addition to the scans, one-minute integrated measurements were collected at each 30-foot interval of the floor of each trench using the quadpancake probes. These measurements were collected to provide an estimate of the average amount of contamination that exists on the trench surfaces but that would not necessarily be detected during the scans. Trench $\mathrm{C}$ could not be completely surveyed. The trench was cluttered with excessive debris which prevented complete coverage during the survey; however, a "best effort" was made to spot-check the trench for any anomalous contamination areas.

\subsubsection{Tunnels}

Two tunnels are associated with the 190-C facility. For the purpose of reference, these will be labeled as North Tunnel and South Tunnel. These tunnels enter the basement of 190-C at the north and south corners of the east wall as shown in Fig. 2. The entire length and shape of each tunnel is shown in Fig. 3.

At the time of the site survey the tunnel areas were zoned as radiological contamination areas. Considering this, the quad-pancake detectors used for measuring the gross direct beta contamination in the tunnels were placed in quart-sized plastic bags with a nominal thickness of $\sim 1.5 \mathrm{mil}$ (density thickness of $\sim 3.5 \mathrm{mg} / \mathrm{cm}^{2}$ ). This was done to prevent contamination of the probe surfaces. Appropriate consideration was given to the presence of this cover when selecting a detection efficiency to convert data for final reporting.

Three static 0.1-min integrated counts were collected at each 10-foot interval along the length of each tunnel. The measurement positions are indicated on Fig. 3. For reference, a lineal grid was used along the length of each tunnel. The zero point was set at the SW corner of each tunnel with the $x$ axis running South to North and the $y$ axis running West to East. In addition to the static measurements, sparse scanning was performed between measurement points with the intent of checking for relative uniformity of the surface contamination. The contamination level between successive measurement points was found to be generally uniform and, as such, the static measurements are assumed to be representative of the contamination surrounding them.

\subsubsection{Main Floor Bay Area}

The main floor bay area is a relatively large expanse of interior space and, at the time of this survey, was still occupied by what appeared to be large hydraulic pump units. The ceiling is very high with spanned girder beams and truss support. As diagrammed in Fig. 4, this area occupies approximately the western two-thirds of the building. Also shown in the diagram is a separate cluster of rooms occupying approximately the eastern one-third of the building on the main level. Not shown in the figure is a mezzanine area directly above this cluster of rooms. References to a mezzanine area in the building apply to this area above the rooms. 


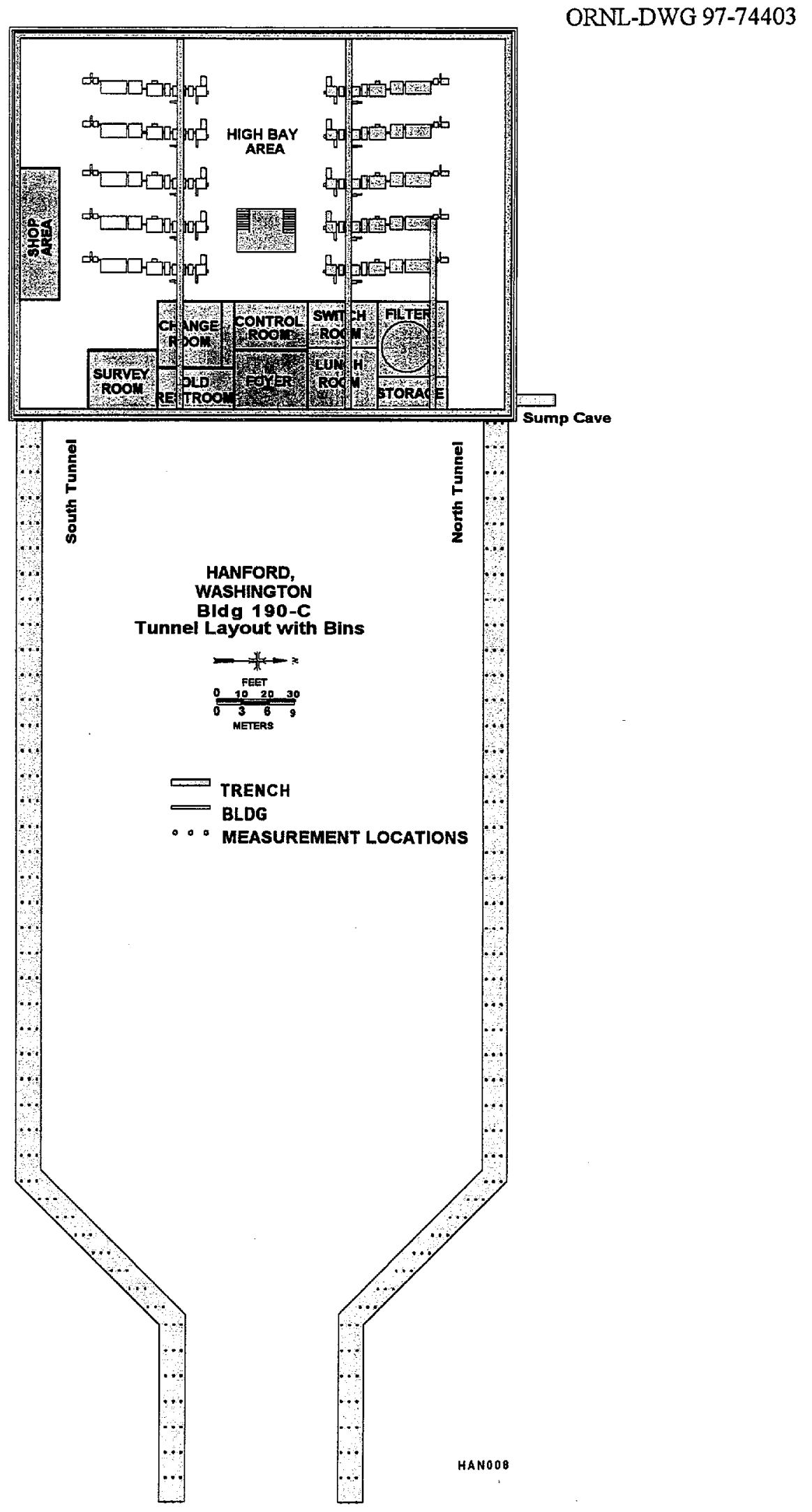

Fig. 3. 105-C water process tunnels showing fixed-point measurement locations. 

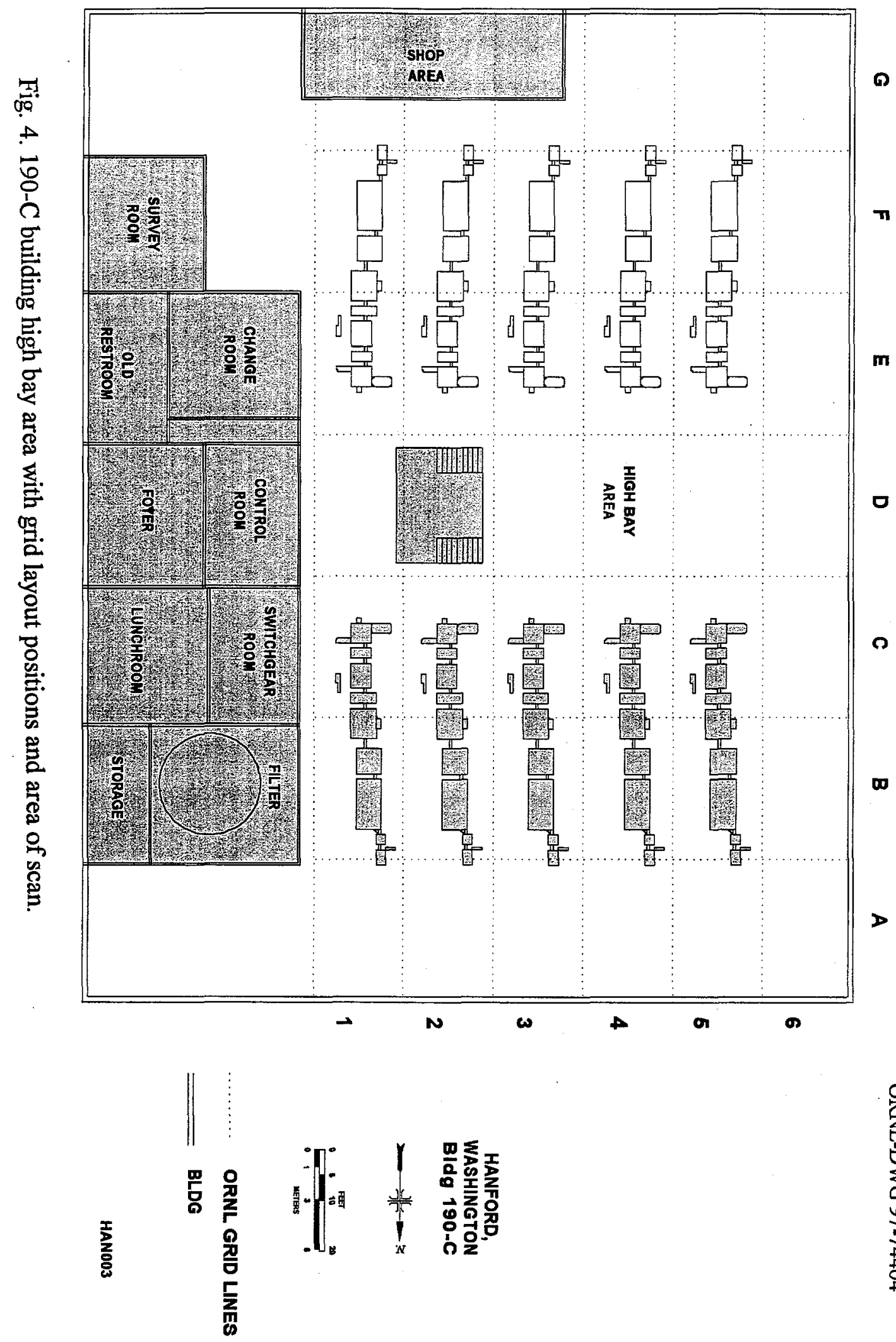

足 
To facilitate referencing measurements, a grid was established across the bay area as shown in Fig. 4. Based on conversations with site personnel and previous document reviews, it was determined that the temporary filter maintenance area had been assembled in the NW region of the building, which correlates to an approximate grid range of A3 through A6.

A thorough beta surface contamination scan was performed in the region which had been used for filter maintenance, i.e., the region bounded by the grid range A3 through A6. In addition to this comprehensive scan, dispersed scans were performed throughout the remainder of the bay area with special emphasis placed on cracks, seams, pitted concrete and any other areas that would appear to easily retain loose dust. Integrated 1-minute count measurements were collected with both beta and alpha measurement equipment at each grid intersection shown by the dashed lines on Fig. 4. The purpose of these measurements was to identify and quantify any potential largearea, low-level dispersed contamination that would not be easily detected during the scan surveys and spot checks.

Limited spot checks were performed on beams above the area where the filter maintenance had occurred, at random points on the hydraulic pump units, hand rails, steel grates and other nonconcrete surfaces and items. This task included direct measurements primarily for betaemitting radionuclides, although direct alpha measurements were also made at random points across the bay area.

\section{RESULTS}

The following sections describe the data collected from each of the surveyed areas listed in Section 2, in addition to conversion factors used and any other notable observations.

\subsection{Background Measurements}

The majority of the measurements collected during this survey were collected from concrete surfaces. After discussions with site personnel and checking various parts of the building, it was decided that the floor area in the basement would provide a good background measurement location for the building concrete. The primary basement floor elevation does not appear to have ever been contaminated. Ten representative background measurements for the detection equipment were collected from this area for one detector each of the quad-detector and the $\mathrm{NaI}$ scintillator. Note that the background response of the quad-detector is exactly 4 times that of the single pancake detector. The results for these measurements are listed in Table 2. Based on these measurements, the background values used for each type of detector were as follows: single detector pancake $=50 \mathrm{cpm}$, quad-detector pancake $=210 \mathrm{cpm}$ and NaI scintillator $=3000 \mathrm{cpm}$. 
Table 2. Detector background measurements

\begin{tabular}{|c|c|}
\hline $\begin{array}{c}\text { GM Pancake Quad-Detector } \\
\text { (cpm) }\end{array}$ & $\begin{array}{l}\text { NaI Scintillator } \\
\text { (x 1000 cpm) }\end{array}$ \\
\hline $\begin{array}{l}225 \\
209 \\
206 \\
199 \\
220 \\
230 \\
232 \\
183 \\
203 \\
202\end{array}$ & $\begin{array}{l}2.6 \\
3.3 \\
2.9 \\
2.6 \\
2.5 \\
3.3 \\
3.1 \\
3.0 \\
3.0 \\
3.5\end{array}$ \\
\hline Average & 3.0 \\
\hline
\end{tabular}

\subsection{Radionuclides and Detection Efficiencies}

Swipes collected from the tunnel areas were analyzed by gamma spectrometry and gross beta counting to determine whether or not the gamma-emitting radionuclide to total beta emission rate was consistent with what had been previously reported. The previously reported concentrations, as discussed in Section 1, were reported to be as follows: ${ }^{137} \mathrm{Cs} 46 \%$ (by activity), ${ }^{90} \mathrm{Sr}(53 \%$ by activity) and all other (1\%). For purposes of comparison, it was assumed that the only radionuclides existing in the tunnel and trench areas at significant levels were ${ }^{137} \mathrm{Cs}$ and ${ }^{90} \mathrm{Sr}$. Using this assumption and the results from the gamma spectrometry analysis and gross beta analysis of the swipes, the relative concentrations of the radionuclides were determined to be: ${ }^{137} \mathrm{Cs}\left(\sim 80 \%\right.$ by activity) and ${ }^{90} \mathrm{Sr}(\sim 20 \%$ by activity).

The original radionuclide data was compiled from analysis of samples collected from within the tunnel areas. The data compiled during this survey is based on analysis of swipes collected from within the same area. Since it is not possible to know which of these analyses is more accurate, it was decided to use the originally reported ratios when determining detection efficiencies in these areas.

\subsection{Trench Data}

The amount of activity in the basement trenches could not be truly determined since the entire trench surface had been painted with about three coats of paint. A correction for the presence of the paint was estimated based on calibrated measurements through a similar amount of absorbing 
material, but it is not possible to know the true thickness of the paint at any given point. For this reason, it is advisable to consider the results from the trench areas as "best" estimates.

The results of the systematic direct beta measurements collected from the trench areas are presented in Table 3. The data has been grouped into four categories; each category describes the area or reference grid from which the data was collected, as shown on Fig. 2. The detection efficiency was corrected to account for the layers of paint on the trench surfaces, assuming the radionuclide mixture presented in Section 3.2. The resulting detection efficiency for the beta detectors in this area for the radionuclide mix and covering material was calculated to be $\sim 0.19 \mathrm{cpm}$ per total (gross) beta dpm.

A localized region of higher contamination was identified during radiation scans of the trench area in the NE corner of the basement perimeter trench as detailed in Fig. 5. Additional measurements were collected in this region with the purpose of evaluating the magnitude of above-average contamination in the area. Points A and B on Fig. 5 indicate specific locations where atypically high radiation levels were observed. Location $A$ was an approximately $1-\mathrm{m}^{2}$ area on the wall of the trench with a total direct beta measurement of $\sim 34,000 \mathrm{dpm} / 100 \mathrm{~cm}^{2}$, and location $B$ indicates an expansion crack in the concrete with a direct gamma reading of approximately $0.2 \mathrm{mR} / \mathrm{h}$ at contact with the seam. Based on a combination of independent gamma and beta measurements, it was determined that the contamination in the crack was at least deeper than what could be penetrated by the beta emissions.

\subsection{Tunnel Data}

The results of the systematic direct beta measurements collected from the floor of each tunnel are presented in Table 4. The gross alpha and beta analysis results for transferrable swipes collected from within the tunnels are presented in Table 5. Generally, the tunnels are contaminated along the entire length to varying levels as indicated by the data. It appears that the area running along the center of the tunnel floors where personnel can easily walk has the least amount of contamination, with significantly higher levels to the sides underneath the transfer piping.

The average contamination levels in the north and south tunnels were found to be $\sim 17,000$ and $\sim 19,000 \mathrm{dpm} / 100 \mathrm{~cm}^{2}$, respectively, with a wide variation in the amount from area to area. As mentioned in Sect. 2.4.2, the detectors were placed in plastic bags to prevent contamination of the probes. The detection efficiency was corrected to account for this, assuming the radionuclide mixture presented in Section 3.2. The resulting detection efficiency for the beta detectors in this area for the radionuclide mix and covering material was calculated to be $\sim 0.21 \mathrm{cpm}$ per total (gross) beta $\mathrm{dpm}$.

Each data point collected is believed to reasonably estimate the average amount of contamination within that specific area of the tunnel, so a direct average of the data is an acceptable method for determining the overall mean. The contamination in the tunnels is loose but only slightly 
Table 3. Surface contamination measurements from the $190-\mathrm{C}$ basement trenches

\begin{tabular}{|c|c|}
\hline $\begin{array}{c}\text { Grid location } \\
\text { (ft) }\end{array}$ & $\begin{array}{l}\text { Total direct } \beta \\
\left(\operatorname{dpm} / \mathbf{1 0 0} \mathrm{cm}^{2}\right)^{*}\end{array}$ \\
\hline \multicolumn{2}{|c|}{ Perimeter of basement } \\
\hline $\begin{array}{r}0 \\
30 \\
60 \\
90 \\
120 \\
150 \\
180 \\
210 \\
240 \\
270 \\
300 \\
330 \\
360 \\
390 \\
420 \\
450 \\
480 \\
510 \\
540 \\
570 \\
600 \\
630 \\
660 \\
\end{array}$ & $\begin{array}{r}760 \\
760 \\
720 \\
1500 \\
480 \\
1800 \\
2300 \\
1100 \\
610 \\
1000 \\
900 \\
240 \\
690 \\
860 \\
1500 \\
440 \\
110 \\
200 \\
400 \\
240 \\
200 \\
180 \\
270 \\
800\end{array}$ \\
\hline \multicolumn{2}{|c|}{ Trench A (South) } \\
\hline $\begin{array}{r}30 \\
60 \\
90 \\
120 \\
150 \\
\text { Average }\end{array}$ & $\begin{array}{r}{[-50]} \\
{[-440]} \\
220 \\
{[-60]} \\
430 \\
\\
20\end{array}$ \\
\hline
\end{tabular}

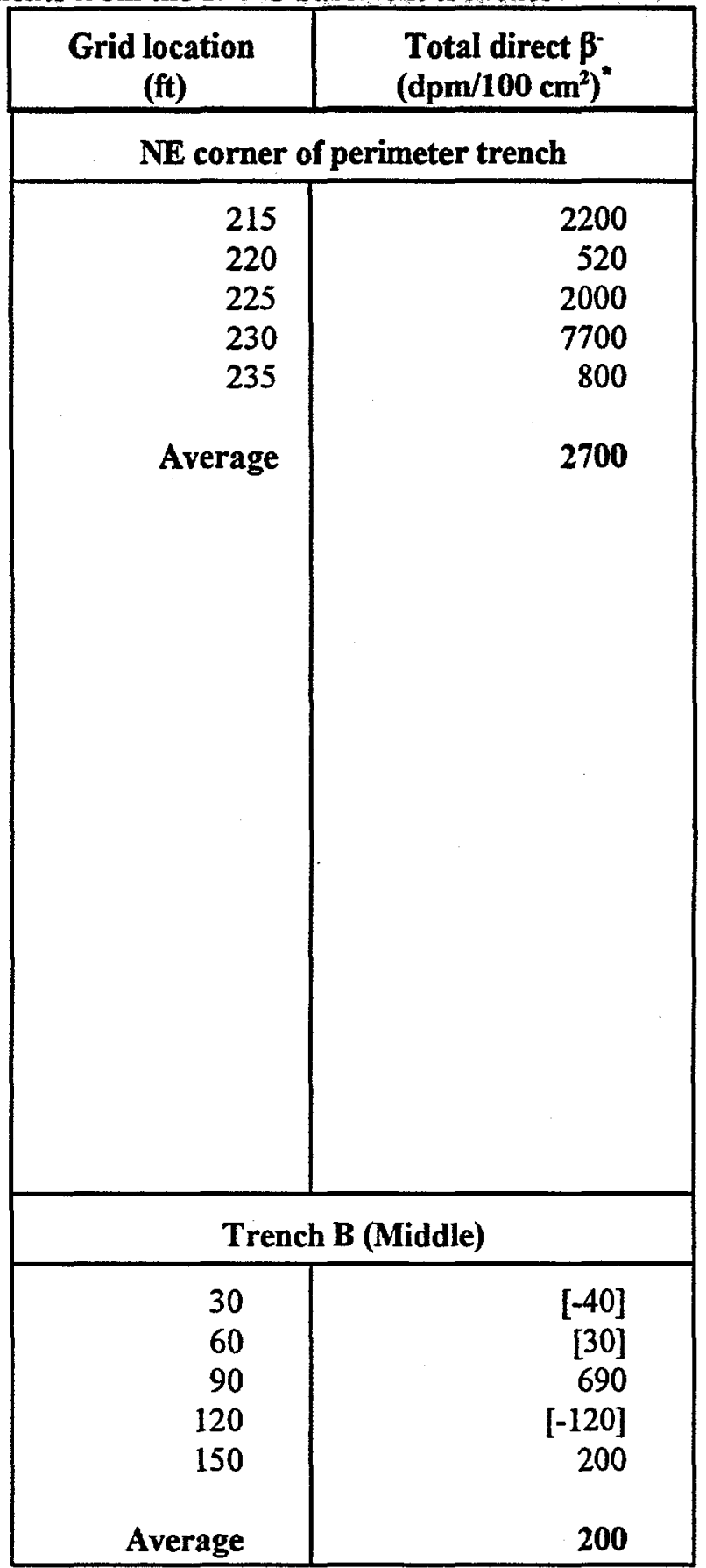

*All values represent the actual measurement less the background response of the detector used. A value in brackets [\#\#] indicates that the measurement was not discernable from the background response of the detector. The critical detection level for direct beta $(\beta)$ measurements was $\sim 280 \mathrm{dpm} / 100 \mathrm{~cm}^{2}$. The MDC for direct beta measurements was $\sim 600 \mathrm{dpm} / 100 \mathrm{~cm}^{2}$. 


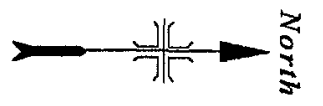

Plan View
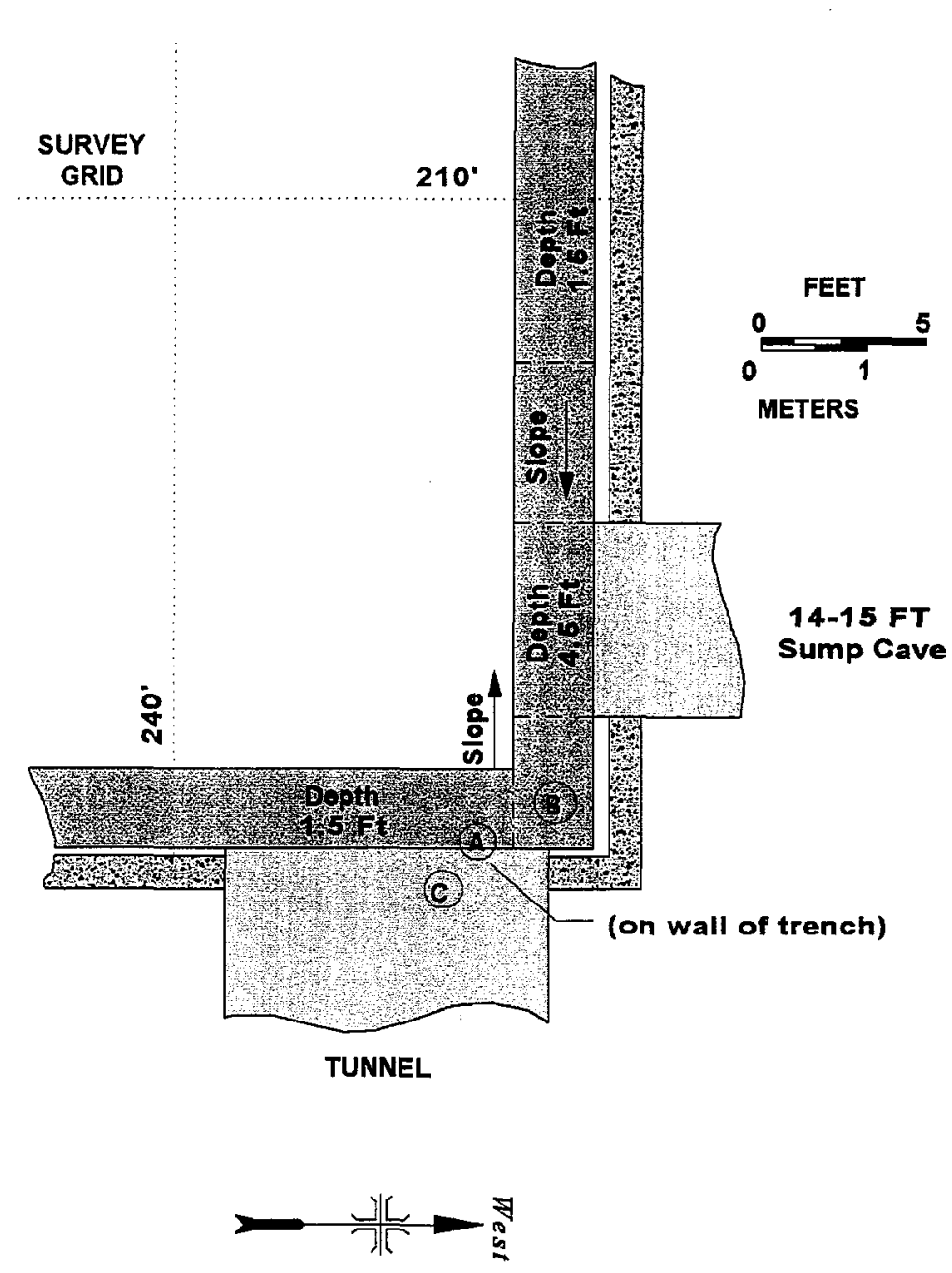

Side View

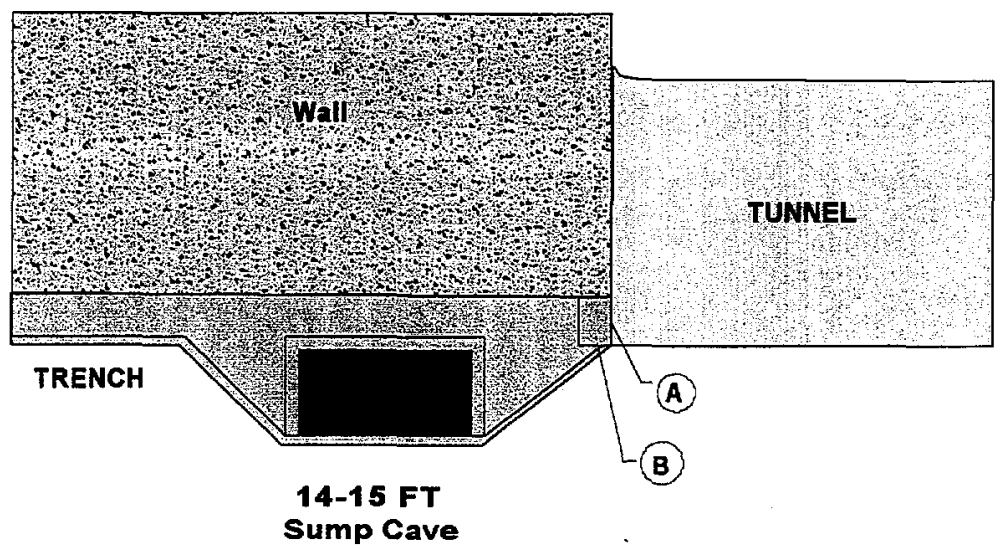

Fig. 5. 190-C basement trench detail showing region of interest near the north tunnel entrance. 
Table 4. Surface contamination measurements from the 190-C water process tunnels (beta measurements collected on the floor surface)

\begin{tabular}{|c|c|c|c|c|c|c|}
\hline \multirow[b]{2}{*}{$\bar{X}$ Location (ft) } & \multicolumn{3}{|c|}{$\begin{array}{c}\text { North Tunnel } \\
\text { Total } \\
\text { direct } \beta \\
\left(\mathrm{dpm} / 100 \mathrm{~cm}^{2}\right)^{*}\end{array}$} & \multicolumn{3}{|c|}{$\begin{array}{c}\text { South Tunnel } \\
\text { Total } \\
\text { direct } \beta \\
\left(\operatorname{dpm} / 100 \mathrm{~cm}^{2}\right)^{*}\end{array}$} \\
\hline & & ocation ( & -9 & & Y Locat & ) \\
\hline 0 & 14000 & 8000 & {$[-310]$} & [0] & [460] & 1500 \\
\hline 10 & 28000 & [230] & {$[-230]$} & 920 & [310] & 29000 \\
\hline 20 & 30000 & {$[310]$} & {$[-150]$} & [380] & [310] & 31000 \\
\hline 30 & 24000 & {$[0]$} & [0] & {$[-384]$} & {$[0]$} & 38000 \\
\hline 40 & 5200 & [460] & {$[-150]$} & [150] & [310] & 12000 \\
\hline 50 & 1600 & {$[-690]$} & [230] & {$[80]$} & 770 & 8800 \\
\hline 60 & 2800 & {$[-380]$} & {$[-460]$} & {$[-154]$} & {$[-77]$} & 5300 \\
\hline 70 & 11000 & {$[-150]$} & 850 & {$[-77]$} & 17000 & 25000 \\
\hline 80 & 24000 & {$[80]$} & 610 & 1100 & 19000 & 26000 \\
\hline 90 & 41000 & [0] & [0] & 36000 & 29000 & 33000 \\
\hline 100 & 44000 & {$[-230]$} & {$[-690]$} & 32000 & 35000 & 35000 \\
\hline 110 & 32000 & {$[-150]$} & {$[-770]$} & 32000 & 36000 & 36000 \\
\hline 120 & 38000 & {$[-80]$} & 920 & 24000 & 25000 & 2100 \\
\hline 130 & 45000 & {$[460]$} & 1100 & 35000 & 40000 & {$[80]$} \\
\hline 140 & 56000 & {$[-150]$} & {$[-80]$} & 33000 & 37000 & 32000 \\
\hline 150 & 53000 & $610^{\circ}$ & {$[-540]$} & 31000 & 30000 & 37000 \\
\hline 160 & 51000 & 850 & {$[-80]$} & 31000 & 34000 & 35000 \\
\hline 170 & 57000 & {$[-310]$} & {$[-380]$} & 31000 & 38000 & 48000 \\
\hline 180 & 48000 & 770 & {$[-380]$} & 1400 & 41000 & 28000 \\
\hline 190 & 55000 & {$[-150]$} & {$[-310]$} & 690 & 35000 & 29000 \\
\hline 200 & 50000 & 11000 & 610 & [380] & 40000 & 34000 \\
\hline 210 & 51000 & {$[460]$} & {$[-150]$} & [80] & 1200 & 30000 \\
\hline 220 & 47000 & [540] & {$[-80]$} & {$[-154]$} & 1100 & 37000 \\
\hline 230 & 53000 & 850 & 690 & {$[-154]$} & 610 & 39000 \\
\hline 240 & 52000 & 12000 & {$[150]$} & {$[-307]$} & 1500 & 40000 \\
\hline 250 & 54000 & {$[310]$} & {$[-380]$} & $610^{\circ}$ & 1200 & 35000 \\
\hline 260 & 78000 & 1400 & {$[380]$} & {$[-154]$} & 690 & 42000 \\
\hline 270 & 66000 & 920 & {$[380]$} & {$[230]$} & 1600 & 32000 \\
\hline 280 & 48000 & 1600 & 1200 & {$[0]$} & {$[150]$} & 36000 \\
\hline 290 & 32000 & [540] & 920 & 1300 & 37000 & 34000 \\
\hline 300 & 48000 & 1200 & {$[-610]$} & {$[80]$} & 41000 & 43000 \\
\hline
\end{tabular}


18

Table 4 (continued)

\begin{tabular}{|c|c|c|c|c|c|c|}
\hline & \multicolumn{3}{|c|}{ North Tunnel } & \multicolumn{3}{|c|}{ South Tunnel } \\
\hline & \multicolumn{3}{|c|}{$\begin{array}{c}\text { Total } \\
\operatorname{direct} \beta^{-} \\
\left(\operatorname{dpm} / 100 \mathrm{~cm}^{2}\right)^{*}\end{array}$} & \multicolumn{3}{|c|}{$\begin{array}{c}\text { Total } \\
\text { direct } \beta^{-} \\
\left(\mathrm{dpm} / 100 \mathrm{~cm}^{2}\right)^{*}\end{array}$} \\
\hline \multirow[t]{2}{*}{ X Location (ft) } & \multicolumn{3}{|c|}{ Y Location (ft) } & \multicolumn{3}{|c|}{ Y Location (ft) } \\
\hline & -3 & -6 & -9 & -3 & -6 & -9 \\
\hline 310 & 43000 & 770 & 610 & [460] & 2200 & 32000 \\
\hline 320 & 49000 & 610 & 540 & {$[80]$} & 610 & 29000 \\
\hline 330 & 48000 & 1200 & [80] & [80] & 690 & 30000 \\
\hline 340 & 49000 & 2000 & 770 & 610 & [230] & 33000 \\
\hline 350 & 51000 & 1400 & [80] & {$[-230]$} & 1100 & 29000 \\
\hline 360 & 50000 & 4200 & 540 & 770 & 61000 & 30000 \\
\hline 370 & 39000 & 52000 & 2200 & 47000 & 50000 & 30000 \\
\hline 380 & 41000 & 12000 & 1100 & {$[80]$} & 1200 & 22000 \\
\hline 390 & 50000 & 690 & 690 & {$[380]$} & 2000 & 36000 \\
\hline 400 & 65000 & {$[-310]$} & 460 & {$[-154]$} & 1200 & 47000 \\
\hline 410 & 59000 & {$[230]$} & 850 & 1200 & 72000 & 32000 \\
\hline 420 & 54000 & [230] & 540 & 690 & 31000 & 39000 \\
\hline 430 & 52000 & 2000 & 770 & {$[460]$} & 43000 & 19000 \\
\hline 440 & 49000 & 54000 & 16000 & 2200 & 40000 & 18000 \\
\hline 450 & 19000 & 52000 & 63000 & 32000 & 33000 & 25000 \\
\hline
\end{tabular}

*All values represent the actual measurement less the background response of the detector used. A value in brackets [\#\#] indicates that the measurement was not discernable from the background response of the detector. The critical detection level for direct beta $(\beta)$ measurements was $\sim 810 \mathrm{dpm} / 100 \mathrm{~cm}^{2}$. The MDC for direct beta measurements was $\sim 1900 \mathrm{dpm} / 100 \mathrm{~cm}^{2}$. 
Table 5. Swipe analysis results

\begin{tabular}{|l|l|c|c|}
\hline Sample ID & Location & $\begin{array}{c}\text { Gross } \boldsymbol{\beta}^{-} \\
\left(\mathbf{d p m} / \mathbf{1 0 0} \mathbf{c m}^{\mathbf{2}}\right)^{*}\end{array}$ & $\begin{array}{c}\text { Gross } \boldsymbol{\alpha} \\
\left(\mathbf{d p m} / \mathbf{1 0 0} \mathbf{c m}^{\mathbf{2}}\right)^{*}\end{array}$ \\
\hline V1T & North tunnel: $130^{\prime},-3^{\prime}$ & 710 & {$[0]$} \\
V2T & North tunnel: $140^{\prime},-3^{\prime}$ & 1000 & {$[3]$} \\
V3T & North tunnel: $150^{\prime},-3^{\prime}$ & 100 & nc \\
V4T & North tunnel: $160^{\prime},-3^{\prime}$ & 220 & {$[0]$} \\
V5T & North tunnel: $250^{\prime},-3^{\prime}$ & 300 & {$[3]$} \\
V6T & North tunnel: $450^{\prime},-9^{\prime}$ & 210 & {$[0]$} \\
V7T & Bay Area, overhead beam & 70 & {$[0]$} \\
V8T & South tunnel: $0^{\prime},-9^{\prime}$ & nc \\
V9T & South tunnel: $100^{\prime},-9^{\prime}$ & {$[-62]$} & nc \\
V10T & South tunnel: $200^{\prime},-6^{\prime}$ & {$[9]$} & {$[3]$} \\
V11T & South tunnel: $300^{\prime},-9^{\prime}$ & 320 & nc \\
V12T & South tunnel: $400^{\prime},-9^{\prime}$ & {$[38]$} & nc \\
V13T & South tunnel: $450^{\prime},-6^{\prime}$ & {$[29]$} & nc \\
V14T & Bay Area, overhead beam & 62 & {$[0]$} \\
V15T & Bay Area, overhead beam & {$[0]$} & {$[0]$} \\
\hline
\end{tabular}

*All values represent the actual measurement less the background response of the detector used. A value in brackets [\#\#] indicates that the measurement was not discernable from the background response of the detector. The critical detection level for the beta $(\beta)$ counter was $\sim 60 \mathrm{dpm}$. The MDC for the beta counter was $\sim 170 \mathrm{dpm} / 100 \mathrm{~cm}^{2}$. The critical detection level for alpha $(\alpha)$ counter was $\sim 5 \mathrm{dpm}$. The MDC for the alpha counter was $\sim 20 \mathrm{dpm}$.

"nc These swipes were not counted for alpha contamination. 
transferrable. Swipes collected from areas with direct measurements of $\sim 60,000 \mathrm{dpm} / 100 \mathrm{~cm}^{2}$ showed transferrable quantities of $\sim 1,000 \mathrm{dpm} / 100 \mathrm{~cm}^{2}$, or approximately $2 \%$ by activity.

\subsection{Bay Area Data}

The results of the systematic direct alpha and beta measurements collected from the bay floor area are presented in Table 6. The gross alpha and beta analysis results for transferrable swipes collected from the beams over the bay area are presented in Table 5. Although the direct alpha measurements show some slightly positive results, this is most likely due to radon daughters that have plated onto the concrete surface. In either case, the values are less than applicable release limits. No elevated regions of radioactive contamination were identified within the bay area.

\section{CONCLUSIONS}

Based on findings from this survey, together with data provided by the remedial action contractor, the building surfaces in the 190-C Main Pumphouse Facility, with the exception of the trenches and tunnels, conform to the surface contamination applicable guidelines for contamination at this site (U. S. DOE 1990). Although the contamination levels in the tunnels and trenches exceeded the established DOE release limits, the average radiation levels in these areas were found to be less than those reported by the remedial action contractor. 
Table 6. Surface contamination measurements from the 190-C main floor bay area

\begin{tabular}{|c|c|c|}
\hline Grid location & $\begin{array}{c}\text { Total } \\
\text { direct } \beta \\
\left(\operatorname{dpm} / 100 \mathrm{~cm}^{2}\right)^{*}\end{array}$ & $\begin{array}{c}\text { Total } \\
\text { direct } \alpha \\
\left(\mathrm{dpm} / 100 \mathrm{~cm}^{2}\right)^{*}\end{array}$ \\
\hline $\begin{array}{l}\text { A1 } \\
\text { A2 } \\
\text { A4 } \\
\text { A5 } \\
\text { A6 } \\
\text { B1 } \\
\text { B2 } \\
\text { B3 } \\
\text { B4 } \\
\text { B5 } \\
\text { B6 } \\
\text { C1 } \\
\text { C2 } \\
\text { C3 } \\
\text { C4 } \\
\text { C5 } \\
\text { C6 } \\
\text { D1 } \\
\text { D2 } \\
\text { D3 } \\
\text { D4 } \\
\text { D5 } \\
\text { D6 } \\
\text { E1 } \\
\text { E2 } \\
\text { E3 } \\
\text { E4 } \\
\text { E5 } \\
\text { E6 }\end{array}$ & $\begin{array}{c}{[160]} \\
{[230]} \\
{[160]} \\
{[-590]} \\
{[90]} \\
{[130]} \\
560 \\
{[-630]} \\
{[-410]} \\
{[-50]} \\
{[90]} \\
{[-130]} \\
{[-520]} \\
450 \\
{[-520]} \\
{[-340]} \\
{[50]} \\
{[-450]} \\
{[-50]} \\
{[-380]} \\
{[-270]} \\
{[-90]} \\
700 \\
{[-230]} \\
{[130]} \\
{[-270]} \\
{[20]} \\
{[50]} \\
{[200]} \\
{[130]}\end{array}$ & $\begin{array}{c}60 \\
{[0]} \\
{[0]} \\
30 \\
{[9]} \\
{[0]} \\
40 \\
30 \\
{[20]} \\
{[0]} \\
{[0]} \\
{[0]} \\
{[-9]} \\
{[0]} \\
{[0]} \\
50 \\
50 \\
{[9]} \\
{[20]} \\
{[9]} \\
{[0]} \\
{[9]} \\
30 \\
40 \\
{[-9]} \\
{[9]} \\
30 \\
{[-20]} \\
{[-9]} \\
{[-9]}\end{array}$ \\
\hline
\end{tabular}


Table 6 (continued)

\begin{tabular}{|c|c|c|}
\hline Grid location & $\begin{array}{c}\text { Total } \\
\text { direct } \boldsymbol{\beta}^{-} \\
\left(\mathbf{d p m} / \mathbf{1 0 0} \mathbf{c m}^{\mathbf{2}}\right)^{*}\end{array}$ & $\begin{array}{c}\text { Total } \\
\text { direct } \boldsymbol{\alpha} \\
\left(\mathbf{d p m} / \mathbf{1 0 0} \mathbf{~ c m}^{\mathbf{2}}\right)^{*}\end{array}$ \\
\hline F1 & 520 & {$[-20]$} \\
F2 & {$[-130]$} & {$[0]$} \\
F3 & {$[130]$} & {$[9]$} \\
F4 & {$[20]$} & {$[9]$} \\
F5 & {$[160]$} & {$[-9]$} \\
F6 & {$[160]$} & {$[-9]$} \\
G2 & {$[50]$} & {$[20]$} \\
G3 & {$[160]$} & {$[-9]$} \\
G4 & {$[-270]$} & {$[-9]$} \\
G5 & {$[340]$} & {$[-20]$} \\
G6 & {$[-410]$} & {$[-9]$} \\
\hline
\end{tabular}

*All values represent the actual measurement less the background response of the detector used. A value in brackets [\#\#] indicates that the measurement was not discernable from the background response of the detector. The critical detection level for direct beta measurements was $\sim 600 \mathrm{dpm} / 100 \mathrm{~cm}^{2}$. The MDC for direct beta $\left(\beta^{-}\right)$measurements was $\sim 1300 \mathrm{dpm} / 100 \mathrm{~cm}^{2}$. The critical detection level for direct alpha $(\alpha)$ measurements was $\sim 30 \mathrm{dpm} / 100 \mathrm{~cm}^{2}$. The MDC for direct alpha measurements was $\sim 90 \mathrm{dpm} / 100 \mathrm{~cm}^{2}$. As with all surface alpha measurements, these estimates of detection ability assume only a small amount of absorption in the surface material. For aged concrete, the absorption can be as high as $100 \%$ because the material may have eroded into the pores or may have been covered by other coating materials. For this worse case, alpha emissions cannot penetrate through to be measured and will result in false negative values. 


\section{REFERENCES}

Fasso, J. E. July 1996. Activity Hazards Analysis for the Demolition of 190-C, 100-C Area, Bechtel Hanford, Inc., Richland, Washington.

Harris, R. A and S. L. Winslow. March 1996. Draft 190-C Facility Release Plan, Bechtel Hanford, Inc., Richland, Washington.

Kennedy, Jr., W. E. and M. P. Moeller. September 1996. Draft Application for Approval of Derived Authorized Limits for the Release of the 190-C Trenches and 105-C Process Water Tunnels at the Hanford Site: Volume 2-Source Term Development. Report to Bechtel Hanford, Inc., under Job Order No. 0500X-SC-G051, Richland, Washington.

Marske, S. G. March 1996. Draft Project Plan for the 190-C Main Pumphouse Facility Decommissioning. BHI-00535, Rev.00. Bechtel Hanford, Inc., Richland, Washington.

ORNL. 1993. Environmental Technology Section Procedures Manual, ORNL-6645/V11/R2, Health Sciences Research Division, Oak Ridge National Laboratory, Grand Junction, Colorado.

ORNL. 1995. Measurement Applications and Development Group Guidelines, ORNL-6782, Martin Marietta Energy Systems, Inc., Oak Ridge National Laboratory, Oak Ridge, Tennessee.

U.S. DOE. 1988. Verification and Certification Protocol for the Formerly Utilized Sites and Surplus Facilities Management Programs, Office of Environmental Restoration, U.S. Department of Energy, Washington, D.C.

U.S. DOE. 1990. Radiation Protection of the Public and the Environment, DOE Order 5400.5, U. S. Department of Energy. 
APPENDIX A

STATEMENT OF VERIFICATION 


\section{APPENDIX A \\ VERIFICATION STATEMENT FOR 190-C MAIN PUMPHOUSE FACILITY AT THE HANFORD SITE, RICHLAND, WASHINGTON}

An independent assessment of remedial action activities at the 190-C Main Pumphouse Facility at the Hanford Site, Richland, Washington has been accomplished by the Oak Ridge National Laboratory Environmental Assessments Group. The purpose of the assessment was to confirm the site's compliance with DOE applicable guidelines and provide independent measurements of the activity levels in the 190-C trenches and 105-C process water tunnels. The assessment included reviews of the Decontamination and Decommissioning Plan and data provided in the preand post-remedial action surveys. An independent verification survey of the facility was also conducted on November 19-21, 1996.

The independent verification survey included beta and gamma scans, smears for removable contamination, and direct measurements for beta-and-gamma-emitting radionuclides in the trenches and tunnels. Similar measurements and scans, with the addition of alpha measurements, were performed in the bay area of the main floor. The facility was also spot-checked for direct beta-, gamma- and alpha-emitting radionuclides.

Based on findings from this survey, together with data provided by the remedial action contractor, the building surfaces in the 190-C Main Pumphouse Facility, with the exception of the trenches and tunnels, conform to the applicable guidelines for surface contamination at this site (Source: Radiation Protection of the Public and the Environment, DOE Order 5400.5, U. S. Department of Energy, 1990). Although the contamination levels in the tunnels and trenches exceeded the established DOE release limits, the average radiation levels in these areas were found to be less than those reported by the remedial action contractor. 
ORNL/TM-13434

\section{INTERNAL DISTRIBUTION}

1-2. R. L. Coleman

3-4. G. H. Forbes

5. M. K. Jensen

6. V. P. Patania

7. S. M. Smith

8. R. E. Swaja
9. Laboratory Records

10. Central Research Library

11. ORNL Technical Library, $\mathrm{Y}-12$

12-14. MAD Records Center

\section{EXTERNAL DISTRIBUTION}

15. Donald Mackenzie, Office of Environmental Restoration and Waste Management, U. S. Department of Energy, MS EM-442, Washington, D. C. 20585

16. Dr. Anthony Kluk, Office of Environmental Restoration and Waste Management, U. S. Department of Energy, MS EM-441, Washington, D. C. 20585

17. Chris Smith, U. S. Department of Energy, Richland Operations Office, P. O. Box 550, Richland, WA 99352

18. Jeffrey Bruggeman, U. S. Department of Energy, Richland Operations Office, P. O. Box 550, Richland, WA 99352

19-20. Office of Scientific and Technical Information, U.S. Department of Energy, P.O. Box 62, Oak Ridge, TN 37831 